\title{
METHODOLOGICAL BASES FOR SUSTAINABLE FOREST MANAGEMENT MONITORING
}

\author{
Lidiya Mikhailovna Chernyakevich \\ Volga State University of Technology, Russian Federation \\ Yurii Semenovich Andrianov \\ Volga State University of Technology, Russian Federation \\ Tatyana Vladimirovna Mochayeva \\ Volga State University of Technology, Russian Federation
}

\begin{abstract}
Approaches to understanding the essence of the notion of 'sustainable forest management' are systematized. The peculiarities of the Russian experience of forest relations institutionalization on the principles of sustainable development are identified. As the state policy of the Russian Federation in the sphere of forest utilization, protection, preservation and reproduction is targeted at forests retaining and growth, as well as meeting the needs of the population in quality forest products and useful forest properties, the paper reveals the main tendencies of forestry development in the Russian Federation in the period of 2007-2014.In those years, the activity on protection, preservation and reproduction of forests on the state territory of Russia showed the decline in the volume of activities and events. There was a marked tendency towards forest resources loss because of wildfires. Methodological bases for state forest man-agement monitoring with the view of forming 'green economy' in the context of sustainable development and eradication of poverty are defined. The methodology for sustainable forest development monitoring with the strategic goal of sustainable forest management, i.e. support and accrual of forest social and economic functions, is worked out having in mind the indicators of social and economic tasks solving for forestry development and the analysis of the dynamics of perception of social and economic consequences of forest enterprises activity by the representatives of the bodies of local self-administration and social organizations.
\end{abstract}

Key words: sustainable forest management, 'green economy', forest social-economic functions, state forest management in the Russian Federation

\section{INTRODUCTION}

Social and economic development of the society in XX century, focused on fast rates of economic growth, was for a long time carried out without taking into account the exhaustibility of many kinds of natural resources. As a result, the humanity has faced contradictions between the growing needs of the society and the impossibility of the biosphere to meet these needs.

The international agreements of the end of XX and the beginnings of XXI centuries, in which the Russian Federation participated actively, proclaimed the necessity of transition of the world community to sustainable development. The purpose of the state strategy of sustainable development of Russia is maintenance of the balanced solution of social and economic tasks and the problems of preservation of natural resources potential for the sake of both present and future generations.
The idea of interfacing economic, ecological and social aspects of development of the society and forest ecosystems has been realized in the concept of sustainable forest management.

Utilization and reproduction of forests as evolutionary process is determined by branch peculiarities, the main of which isa long period of forest cultivation. Modern results of this process are determined by the organization of forestry, the system of forest management in the past, and the present activities predict the results for future. Therefore, monitoring of real tendencies of utilization and reproduction of forest resources and their objective analysis form the base for information support of all levels and functions of management in developingthe state policy and strategy in the field of utilization, protection, preservation and reproduction of forests, social and economic development of forest sector of economic activity of the state and its regions. 
The goal of the research consists in systematizing methodological ideas and developing a technique forsustainable forest management monitoring with a view ofsustainable forest management, i.e. support and accrual of forest social and economic functions.

The tasks directed on the achievement of the goal of the research:

- to systematize theoretical and methodological approaches to understanding of essence of the notion 'sustainable forest management';

- to reveal the features of the Russian forest relations institutionalization on the principles of sustainable development;

- to define methodological basesfor state forest management monitoring with the view of forming 'green economy'in the context of sustainable development and eradication of poverty;

- to suggest the technique for sustainable forest development monitoring with the strategic aim of sustainable forest management, i.e. support and accrual of forest social and economic functions.

The problems of sustainable development are in the focus of all international summits, forums, symposiums during which the basic processes and tendencies in the field of economy, social development and environment are analyzed, as well as principles, directions of transition of the world community to sustainable development are worked out[09]. The concept of sustainable development was proclaimed in 1992 in Rio de Janeiro by the heads of the states and the governments at the United Nations Conference on Environment and Development. Sustainable development is determined as the one that satisfies current needs, but does not threaten the ability of future generations to satisfy theirs. Sustainable longterm development does not represent a constant state of harmony, rather a process of changes in which the scale of resources exploitation,the direction of capital investments, orientation of technical development and institutional changes are correspond to present and future requirements [08]. At the conference, the basic requirement to organizingforestry relations was put forward, i.e.sustainable forest management.

In the Russian scientific environment there is a set of approaches to disclosing the essence of the notion 'sustainable forest management'.

With reference to forest administering, the strat- egy of sustainable development is considered the strategy of sustainable forest management (sustainable development of forestry). MoiseyevN.A. points out that the term 'Sustainable Forest Management' means 'maintenance', i.e. preservation of an object of management at the levelof its functionality, not supposing deterioration [07].

Professor PetrovA.P. considers that the meaning of the notion 'sustainability' with reference to forestry should be considered in three aspects: ecological, economic and political [11]:

- ecological aspect assumes preservation of the environment and rational use of natural resources,

- economicone is predetermined by limited natural resources, their economic availability,

- political aspect assumes creation and development of the political system providing formation of a legal society, achievement of social stability, as well as legislative consolidation of the property rights over all natural resources and their protection by the constitution.

Pisarenko A.I., Strakhov V.V. have formulated the transition of Russia to the model of sustainable development of the economy without damage to natural ecosystems as the transition from sustainable forest utilization to sustainable forest management, i.e. formation of 'a new theory of forestry' should rely upon ecological and social role of forests [12].

In theFAO research State of the World's Forests 2014 the importance of a social role of forests and the necessity of monitoring of social and economic benefits are marked. Social and economic benefits from forests mainly consist in consumption of forest goods and services. The research underlines the necessity of further strengthening the ties between social and economic benefits and development of more ecologically focused sustainable economy [13].

During the Helsinki and Montreal processes, countries-participants have developed principles, criteria and indicators used in estimation of sustainability of forest management. The criteria for these are a profile of practical activities in the sphere of forest management that provides the achievement of a goal in view. 
The indicators are quantitative and qualitative characteristics, estimations, descriptions, allowing to evaluate, analyze and predict the actions against the corresponding criterion. Russia participated in those international negotiating processes. The results of the discussion onthe criteria and indicators of sustainableforest management laid the basis of the document 'Criteria and indicators of sustainable forest management in the Russian Federation' developed in accordance with international experience insustainability forest managementmonitoring (Table 1).

The requirement to organize forest management on the principles of sustainable development is a law in Russia. The Forest legislation and other forestry regulations of the Russian Federation are based on the following main principles (Figure 1).
Yet, the development of forestry on the principles of sustainable management has not led to expected effectiveness of forests utilization, to the reduction in the level of their damage and destruction, as well as the improvement of quality of forest resources reproduction. The activity in the sphere of forest protection, preservation and reproduction within the territory of the country in 2007-2014 is characterized by the decrease in the amount of works and activities. The steady tendency towardsforest resources loss growth due to various adverse factors, including forest fires, was outlined (Table 2).

Table 1: Criteria for sustainable forest management

\begin{tabular}{|l|}
\hline \multicolumn{1}{|c|}{ European list of criteria for sustainable forest management[2] } \\
\hline $\begin{array}{l}\text { Criterion 1. Maintenance and appropriate accrual of forest resources and their contribution to } \\
\text { global carbon cycle }\end{array}$ \\
\hline Criterion 2. Maintenance of forest ecosystems viability \\
\hline $\begin{array}{l}\text { Criterion 3. Maintenance and preservation of forest productive functions (wood and not wood } \\
\text { products) }\end{array}$ \\
\hline Criterion 4. Maintenance, preservation and accrual of a biodiversity in forest ecosystems \\
\hline Criterion 5. Maintenance and appropriate accrual of protective functions in forest management \\
\hline Criterion 6. Maintenanceof other social and economic functions and conditions \\
\hline Criteria for conservation and sustainable management of temperate and boreal forests [3] \\
\hline Criterion 1. Conservation of biodiversity \\
\hline Criterion 2. Maintenance of forest ecosystems productivity \\
\hline Criterion 3. Maintenance ofsanitary wellbeing and viability of forest ecosystems \\
\hline Criterion 4. Conservationand maintenanceof soil and water resources \\
\hline Criterion 5. Maintenance of the forest contribution to global carbon cycle \\
\hline $\begin{array}{l}\text { Criterion 6. Maintenanceand accrual of long-term complex social and economic benefits aimed at } \\
\text { meeting social needs }\end{array}$ \\
\hline $\begin{array}{l}\text { Criterion 7. Legal, economic and organizational frameworks for forest conservation and sustain- } \\
\text { able management }\end{array}$ \\
\hline \hline \\
\hline Criteria for sustainable forest management in the Russian Federation [4] \\
\hline Criterion 2. Maintenanceof appropriate sanitary state and viability of forests \\
\hline Criterion 3. Conservationandmaintenanceof protective forest functions \\
\hline $\begin{array}{l}\text { Criterion 4. Conservation and maintenance of forests biodiversity and their contribution to global } \\
\text { carbon cycle }\end{array}$ \\
\hline Criterion 5. Maintenance ofsocial and economic functions of forests \\
\hline Criterion 6. Tools of forestry policy for sustainable forest management support \\
\hline
\end{tabular}




\section{MAIN PRINCIPLES OF FOREST LEGISLATION OF THE RUSSIAN FEDERATION}

1. Sustainable forest management, conservation of biodiversity of forests, raising of their potential capacity

2. Conservation of environmental, water protecting, preservative, sanitary-hygienic, health-promoting and other beneficial forest functionswith the aim of providing everyone with favorable environment

3. Forests utilization with the view of their global environmental importance as well as duration of their growth and other natural features of forests

4. Provision of multi-purpose rational non-stop inexhaustible forest utilization to meet the needs of the society in forests and forest resources

5. Forest reproduction and reclamation, increasing its capacity

6. Provision of forests protection and preservation

7. Participation of citizens and non-governmental organizationsin drafting decisions realization of which can affect forests utilization, protection, preservation and reproduction in the ways and forms established by the legislation of the Russian Federation

8. Forests utilization in the ways which do not damage the environment and human health

9. Breaking down the forest types into categories depending on their target purposeand establishing the categories of protective forests depending on their useful functions

10. Inadmissibility of forest utilization by state andlocal administration bodies

11. Paying fee for forest utilization

Figure 1:The principles of forest legislation of the Russian Federation[5]

Table 2: Indicator dynamics of forest protection, maintenance and reproduction in the Russian Federation

\begin{tabular}{|l|c|c|c|c|c|c|c|c|c|}
\hline \multirow{2}{*}{ Indicators } & \multicolumn{3}{|c|}{ Years } & \multicolumn{3}{|c|}{$\begin{array}{l}\text { Annual } \\
\text { mean } \\
\text { growth } \\
\text { rate, } \\
\text { per cent }\end{array}$} \\
\cline { 2 - 10 } & 2007 & 2008 & 2009 & 2010 & 2011 & 2012 & 2013 & 2014 \\
\hline $\begin{array}{l}\text { Forest } \\
\text { repro- } \\
\text { duction, } \\
\text { thds ha }\end{array}$ & 872.2 & 828.4 & 836.7 & 811.5 & 860.0 & 841.7 & 872.3 & 863.0 & 99.8 \\
\hline $\begin{array}{l}\text { planting } \\
\text { in-cluded }\end{array}$ & 202.4 & 191.4 & 181.4 & 170.8 & 196.5 & 184.9 & 186.9 & 187.4 & 98.9 \\
\hline $\begin{array}{l}\text { Forest } \\
\text { stand } \\
\text { lost, } \\
\text { thds ha }\end{array}$ & 319.3 & 273.5 & 446.6 & 801.6 & 418.6 & 378.7 & 619.8 & no data & 111.7 \\
\hline $\begin{array}{l}\text { Number } \\
\text { of wild- } \\
\text { fires, } \\
\text { thdsea }\end{array}$ & 17.8 & 26.3 & 23.2 & 34.8 & 21.1 & 20.2 & 25.3 & 17.1 & 99.4 \\
\hline $\begin{array}{l}\text { Forest } \\
\text { fire area, } \\
\text { thds ha }\end{array}$ & 1036.0 & 2070.0 & 2112.0 & 2027.0 & 1408.0 & 2101.2 & 2733.4 & 3738.2 & 120.1 \\
\hline \hline
\end{tabular}


In 2014 state expenditures onforests protection, maintenance and reproduction amounted to more than 50rubles per 1 ha of forest area, which exceeds almost twice the state returns on their utilization (Figure 2).

A negative tendency in the dynamics of forest resources state and utilization development is characteristic for many countries.

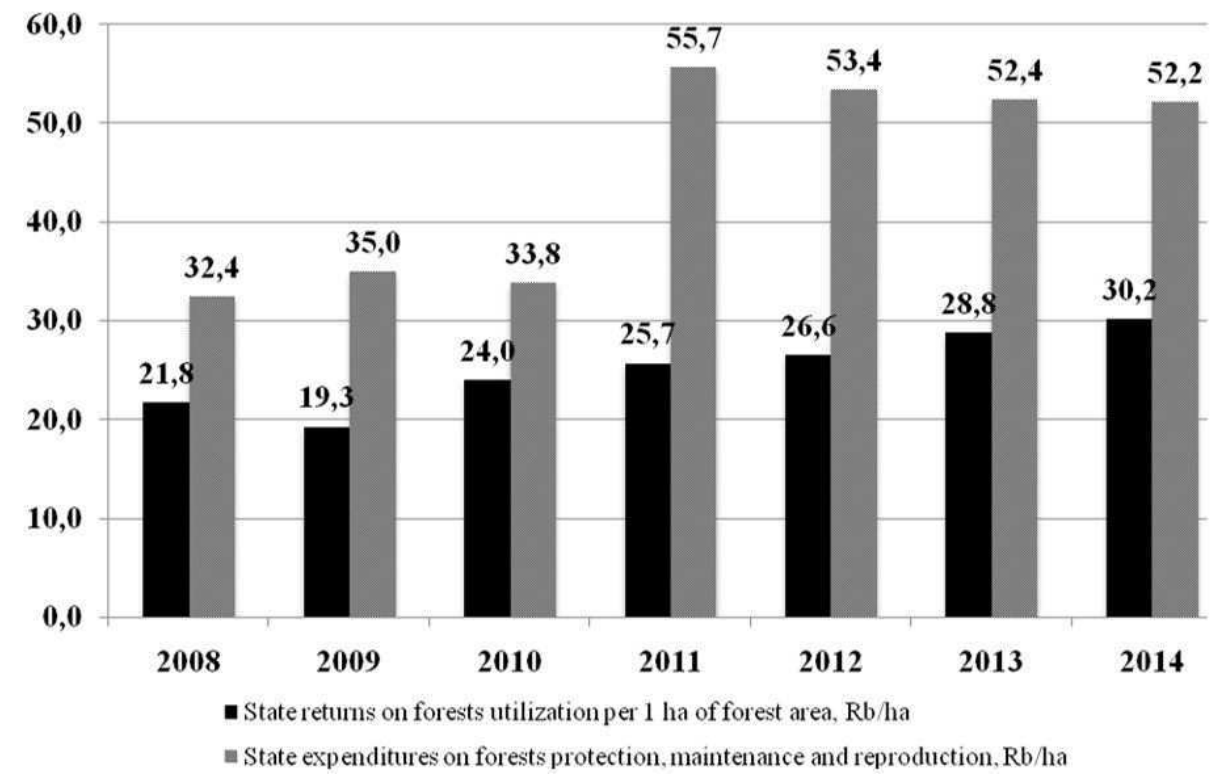

Figure 2: State returns on forests utilization and state expenditures on their protection, maintenance and reproduction, $\mathrm{Rb} / \mathrm{ha}$

During the last two decades, some crises broken out in the worldbecause of climate changes andbiodiversity reduction and connected with power, foodstuff and water resources, as well as the global financial and economic crises. For more effective promotion towards sustainable development some international organizations have developed the concepts of 'green economy' and 'green growth', considering them the 'engines' on the way of transition to sustainable development [1].The 'green economy' is based on the principles of state-private partnership and aspires to correct the existing market and institutional failures. 'Green growth' represents development in the 'green economy' environment.

\section{RESEARCH METHODS}

As far back as the middle of $\mathrm{XX}$ century, Russian academiceconomists in the field of forestry specified the necessity to account all the variety of forest aspects. In particular, Prof. T.S.Lobovikov (1909-1999) defined the scientific bases of forestry as follows,'Biological and silvicultural principles and rules make a substantial part of the complex of scientific foundations of forestry. Its other part is social and economic laws ...'(6).

Developing in line with global tendencies of re- alization of 'the green economic initiative' and development of 'green' economy in the context of sustainable development and liquidation of poverty, the Russian Federation has defined the strategy of 'green' growth, integrating economic, ecological and social interests, to be the state policy in the field of utilization, protection, preservation and reproduction of forests. Realization of state policy in the field of utilization, protection, preservation and reproduction of forests is directed atthe achievement of the following goals [10]:

a) in the sphere of economics they are efficient forest sector management and GDP increase

b) in forest sector on the basis of market demand;

c) in the sphere of ecology they are favorable environment for citizens and preservation of biospheric role ofRussian forests;

d) in social sphere they are growth of a standard of living of the citizens connected with forests and sustainable social and economic development of forest territories.

To realize the state policy in the field of utilization, protection and reproduction of forests the state program of the Russian Federation Devel- 
opment of forestryfor 2013-2020 was adopted. Performance evaluation for forestry development is based on the system of indicators.

The substantial analysis of the system of indicators shows, that they are predominantly directed on revealing of the degree of forests conservation and their contribution to state incomes, not reflectingthe achievement of the established economic and social goals of the state forest policy.

The strategic approach to forest state management allows to generate the hierarchy of its functions: commitment to goal realization, change management, adaptation and self-organizing on the basis of effective utilization of multi-resource forest potential. From the viewpoint of system approach,'purposefulness' is considered a system-forming element. Strategic management is geared at the general objective of the system. The management efficiency is finally determined by the degree of achievement of the goal in view.
The processes monitoring as the system of observing the conditions of objects, phenomena, processes with the aim of their estimation, control, and forecasting allows to estimate the results and correctthe actions of the managing system. The monitoring procedure should be proved and reproduced in time to obtain comparable results and change estimation.

The strategic basis for the development of 'green' economy in the context of sustainable forest management is the effect of decoupling, i.e. dividing of the trends of social and economic growth and depauperization and degradation of forest resources, therefore the technique of monitoring of forest sustainable development should also reflect the dynamics of social and economic results of forestry development and provide research activities and data gathering necessary for definition of at least the following indicators (parameters) (Table 3) [08].

Table 3: Indicators of social and economic results of forestry development

\begin{tabular}{|c|c|c|}
\hline Social and economic goals in view & Indicators & mea units \\
\hline \multirow{3}{*}{$\begin{array}{l}\text { 1. Increase of the contribution of } \\
\text { forest sector into the GDP }\end{array}$} & $\begin{array}{l}\text { Growth of production volumes of } \\
\text { wood and wood products }\end{array}$ & $\%$ \\
\hline & $\begin{array}{l}\text { Growth of production volumes of non- } \\
\text { wood forest products }\end{array}$ & $\%$ \\
\hline & $\begin{array}{l}\text { Growth of production volumes of } \\
\text { products with high added value }\end{array}$ & $\%$ \\
\hline $\begin{array}{l}\text { 2. Increase of the level of occupa- } \\
\text { tion among the population }\end{array}$ & Increase of workplaces & $\%$ \\
\hline $\begin{array}{l}\text { 3. Increase of the level of income } \\
\text { among the population }\end{array}$ & Averagemonthlysalaryincrease & $\%$ \\
\hline \multirow{2}{*}{$\begin{array}{l}\text { 4. Preservation and development } \\
\text { of scientific-technical and innova- } \\
\text { tive capacity }\end{array}$} & $\begin{array}{c}\text { Investments into } R \& D \text { and innovation } \\
\text { infrastructure per } 1 \text { ha of forest area }\end{array}$ & thdsRb/ha \\
\hline & Expenditure growth for staff training & thdsRb/ha \\
\hline $\begin{array}{l}\text { 5. Social infrastructure develop- } \\
\text { ment }\end{array}$ & $\begin{array}{l}\text { Investments into creation and } \\
\text { modernization of the objects of so- } \\
\text { cial infrastructureper } 1 \text { ha of forest } \\
\text { area }\end{array}$ & thdsRb/ha \\
\hline $\begin{array}{l}\text { 6. Creation and improvement of } \\
\text { transport infrastructure }\end{array}$ & $\begin{array}{l}\text { Investments into forest roads } \\
\text { building and maintenanceper } 1 \text { ha } \\
\text { of forest area }\end{array}$ & $\mathrm{Rb} / \mathrm{ha}$ \\
\hline
\end{tabular}

Beside the analysis of objective quantitative indicators of social and economic problems solution in forestry management, the account of qunatitative feedback from local communityis necessary as well. We recommend to interview essential number of local government bodies represen- tatives, social agencies and local population to reveal the dynamics of perception of social and economic consequences of operating performance of forest enterprises in specific territories, as well as the prospects of their development. Interviewing should reveal the opinion of public 
representatives on the following:

1. What is the level of corporate social responsibility of forest enterprises? Do they function as an open system, i.e. interrelated with the environment?

2. Do forest enterprises contribute to the increase of people wellbeing? What isthis shown through?

3. Does the performance of forest enterprises influence quality of the environment people live in? What are the benefits and the drawbacks of such influence?

4. Do forest enterprises come into conflict with the population, local government bodies?

The results of monitoring objective and subjective indicators of social and economic problems solution in forestry development should be used in both forestry development programs elaboration and implementation and their updating.

\section{DISCUSSION}

The aim of the research consists in generalization and systematization of methodological provisions and development of a technique for monitoring sustainable forest management with the strategic purpose of sustainable forest management, i.e. maintenance and augmentation of social and economic functions of forests.

Social and economic development of a society is provided through solving such problems as increase of level of employment of the population, growth of the level of income of the population, preservation and improvement of quality of the environment, preservation and development of scientific, technical and innovative capacity, development of social infrastructure, creation and improvement of transport infrastructure. Forests represent a base element of 'green economy' and they frequently determine the quality of life of the population and the level of development of the economy within a specific territory. Despite the huge standing volume in the Russian Federation (83.1 billion $\mathrm{m} 3$; the second largest in the world, constituting $15.8 \%$ of world reserves), the contribution of a timber complex into GDP is low, approximately amounting to $3 \%$. In that context, in remote from the centers of urbanization areas rich inforests development of loggingand timber processing enterprises issignificant for employment of the population and attraction of investments into the economy of municipali- ties. The forest enterprises should develop as an open system interrelated and tightly bound to the environment, striving to get maximum profit from the entrepreneurial business based on utilization of forest resources; they should not reduce volume and quality of forest ecosystem services and negatively influence the level and quality of life of local population.

Defining the indicators of social and economic development of forestry, it is necessary to bear in mind the strategic goal of sustainable forest management which is purposeful, long-term, economic interrelation of the person and forest ecosystems. Monitoring of such indicators is an important tool for revealing and defining the problems on the way of sustainable development and estimation of effectiveness of measures at all levels of state government.

\section{CONCLUSIONS}

The state policy of the Russian Federation in the field of forest utilization, protection, maintenance and reproduction develops in line withglobal tendencies. Russia has intentionally chosen the strategy of 'green growth' as forest policy. Thus, qualitative analysis of the parameters of realization of the state program for forestry development has revealed, that they do not provide an opportunity for monitoring and estimation of social and economic aspects of sustainable forest management.

According to the forestry legislation, the sustainable forest management monitoring system in the Russian Federation includes carrying out state inventory of forests, state monitoring of forest reproduction as a part of ecological monitoring.

The suggested technique for monitoring of objective indicators (parameters) of social and economic results of forestry development and subjective perception of social and economic consequences of forest enterprises activity by public representatives alongside with qualitative and quantitative indicators of forest resources conditions and their contribution to preservation of favorable environment will allow to provide the balance of interests of the state, business and the population within the framework of sustainable forest management.

\section{ACKNOWLEDGEMENT}

We acknowledge the support from the Russian Humanitarian Science Foundation and the Re- 
public of Mari El within the framework of the regional local competition Volga region territories in the culture and history of Russia 2015 - the Republic of Mari Elunder grant agreement No 15-1212006 'Transformation of reproduction processes in the forest sector of economics of the Republic of Mari El in the innovative development environment: traditions, history, prospects'.

\section{REFERENCES}

1) Green economy: Introduction for politicians, non-governmental organizations and academic researchers of Central Asia / Regional coordination and support for raising the level of regional cooperation between the $\mathrm{EU}$ and Central Asia in the field of environment and water resources (WECOOP). URL: http://infoik.net.kg/images/files/GreenEconomyRu. pdf, retrieved on November 25, 2015.

2) European list of criteria and most suitable indicators (1994).Ministerial Conference on the Protection of Forests in Europe, 16-17 June 1993 in Helsinki, Moscow, 19p.

3) Criteria for conservation and sustainable management of temperate and boreal forests (1995), Moscow, 25p.

4) Criteria and indicators for sustainable forest management in the Russian Federation, URL: http://docs.cntd.ru/document/901706209, retrieved onNovember 25, 2015.

5) Forestry Code of the Russian Federationof 04 December 2006,URL:http://www. consultant.ru/document/cons_doc_LAW_ 64299/,retrieved on November 25, 2015.

6) Lobovikov, T.S. (1972) General conception of forestry and forest industry development forms. Forestry and forest industry of the USSR (for VII International Congress), Moscow: Forest industry, 61-69.

7) Moiseyev, N.A. (2010)Forests of Russia and organizational problems oftheir utilization and reproduction. Forests of Russia: problems, solutions (issues of economics and management organization), Moscow: Vector T\&S, 11 - 226.
8) Mochayeva, T.V. (2009) Methodological approaches to estimation of social and economic results of the forest exploitation project.International cooperation in forest sector: balance of education, science and industry: International Conference Proceedings,Yoshkar-Ola: Mari State Technical University, 194-199.

9) Our common future:Report of the International Commission on the Environment and Development, URL:http://yстойчивоеразвитие.pd/ files/monographs/OurCommonFuture-introduction.pdf,retrieved on November 25, 2015.

10) Foundations of the state policy in the field of utilization, protection,conservation and reproduction in the Russian Federation for the period up to 2030: conf. by instr. N 1724-p. of the Government of the Russian Federation on 26.09.2013,URL: https://www.consultant. ru/document/cons_doc_LAW_152506/, retrieved on November 25, 2015.

11) Petrov, A.P. (1996) Economic and legal foundation of the national forest policy.Forestry, 2, 6-8.

12) Pisarenko, A.I., Strakhov, V.M. (2012) About forest policy in Russia, Moscow, Urisprudentziya, 600p.

13) State of the World's Forests 2014.Enhancing the socioeconomic benefits from forests / Food and Agriculture Organization of the United Nations. FAO, Rome, 2014. URL: http://www.fao.org/3/a-i3710r.pdf, retrieved on May 06, 2016.

Paper sent to revision: 23.12.2015.

Paper ready for publication: 12.05.2016. 